\title{
The effect of different negative parameters on the performance of steel structures
}

\author{
Ercan IŞIK a (D) , Berfin KAYA b (D) Ibrahim Baran KARAȘIN c ${ }^{c}$ (D) \\ a Bitlis Eren University, Department of Civil Engineering, TR-13000, Bitlis Turkey \\ b Bitlis Eren University, Department of Civil Engineering, TR-13000, Bitlis Turkey \\ c Dicle University, Department of Civil Engineering, TR-21000, Diyarabakır Turkey
}

\section{ART I C LE INFO}

\section{Article history:}

Received 02 December 2020

Received in revised form 22 December 2020

Accepted 23 December 2020

\section{Keywords:}

Steel

Soft Story

Irregularity in Plan

Short Column

Hill-Slope Effect

Pushover,

Eigenvalue

\begin{abstract}
A B S T R A C T
In this study, we present the effect of various negativity parameters on steel structures that cause postearthquake damage based on performance-based assessment. In accordance with this purpose, eigenvalue and pushover analysis are carried out for different negativity parameters such as number of story, soft story, short column, hill-slope effect and irregularity in plan for a sample steel structure in this study. Structural models were created over the reference building to cover each negativity parameter within the scope of this study. Natural vibration period, base shear force, target displacements for damage estimation and stiffness values are obtained for each structural model separately. The comparisons with the reference building model results are made. The effect to behavior of structures is determined and a reduction coefficient is proposed, for each negativity parameter, respectively. The proposed coefficients can be used to determine the risk priority in steel structures. It was concluded that each negativity parameter considered in this study reduces the behavior of the building under the effect of earthquakes.
\end{abstract}

\section{Introduction}

The failure of the structures due to their insufficient vulnerability is the one of the main reason of significant loss of life and properties after the earthquakes (Hadzima-Nyarko et al., 2017; Pavić et al., 2020; Harirchian et al., 2020). Vulnerability can be defined simply as sensitivity of exposure to earthquake hazard (Coburn and Spence, 2003). Building stocks vulnerability can be expressed in terms damage potential respect of similar structures subjected to a seismic hazard (s) (Işılk et al., 2018; Harirchian and Lahmer, 2020). The destructive power of seismic hazard reveals some weaknesses in urban environments (Inel and Meral, 2016; Işık et al., 2017). It is important to anticipate and take appropriate measures to reduce vulnerability and expected losses in order to prepare for management in the event of a potential earthquake (Ademović et al., 2020; Arslan et al., 2015). There are many
(C) 2020. Turkish Journal Park Academic. All rights reserved. structural parameters that can adversely affect the vulnerability of structures under earthquake impact (Ișık 2016; Šipoš and Hadzima-Nyarko, 2017). These negative structural parameters are caused by most structural damage and increased the damage amount after devastating earthquake (Yakut, 2004; Sucuoglu and Yazgan, 2003; Chever, 2012). The main negative building characteristics that increase the amount of damage after earthquakes are included in both seismic design codes and rapid seismic assessment methods such as number of story, soft story, short column, hill-slope effect and irregularity in plan as stated in previous studies. (Harirchian, 2020; Sucuoğlu et al., 2007; Yakut et al., 2007; Ozmen et al., 2014; Tesfamariam and Liu, 2010; Alam and Alam, 2012; Jain et al., 2010; Ozcebe et al., 2003). In these studies, include rapid evaluation methods of structures and suggested a coefficient for the negativities generally found in reinforced-concrete (RC) structures.

Within the scope of this study, number of stories, soft story,

\footnotetext{
* Corresponding author.

E-mail address: eisik@beu.edu.tr

ORCID : 0000-0001-8057-065X (Ercan Işık)
} 
short column, hill-slope effect and irregularity in plan, which are among the main parameters that cause vulnerability of buildings, are examined in terms of steel structures. Pushover and eigenvalue analyses were performed to determine how these parameters affect the earthquake behavior of the structures considering the structural models created for each negativity parameter. Natural vibration periods were obtained based on eigenvalue analysis. The base shear force, target displacements for damage estimation and stiffness values were obtained by using pushover analysis. A reduction coefficient is proposed for each negativity parameter considered in this study by using the values obtained from these two analyses. These reduction coefficients that obtained from this study can be used for the rapid assessment method for steel structures. Information is given about analysis and main parameters that taken into consideration in this study. After giving detailed information about the structural characteristics for sample steel structure, the analysis results are stated.

\section{Analysis Types}

In this study, Seismostruct, one of the software related to structures, was used (SeismoSoft, 2018). Two different analyses were carried out such as eigenvalue and pushover analysis.

\subsection{Eigenvalue Analysis}

Eigenvalue analyzes were performed for the building models created for each variable used in this study. Mode shapes and natural frequency for any structure can be obtained by eigenvalue analysis. Material properties always remain constant during the calculation (Antoniou and Pinho 2003; Kutanis et al., 2017; Aksoylu and Arslan, 2019). Briefly, it can be evaluated as pure elastic structural analysis. The cross section can be expressed by material cross-sectional properties such as torsion constant, moment of inertia, modulus of elasticity and stiffness modules (Lou et al., 2017; Nikoo et al., 2017; Zuo and Zha, 2018). Structure related modal period, frequency, modal participation factors, effective modal masses and their percentages can be calculated by eigenvalue analysis.

\subsection{Pushover Analysis}

Pushover analysis is one of the practical and effective methods to determine seismic capacities of structures in the design and evaluation process (Hsiao et al., 2015; Estêvão and Oliveira 2015; Krawinkler and Seneviratna, 1998). This analysis method was developed to understand the nonlinear behaviour characteristics and performance of structures under horizontal loads (Chopra and Goel, 2002; Antoniou and Pinho, 2004; Elnashai, 2001). Many data can be obtained such as the base shear capacity, displacement ductility of the structure, the damages in the structural system elements and the distribution of forces in the structure after damage by pushover analysis (Aydinolglu, 2003; Gupta and Kunnath, 2000; Papanikolaou and Elnashai, 2005; Bracci et al., 1997). The capacity curve representing the relationship between the base shear force and peak displacement is also obtained from the pushover analysis. To obtain this curve, the lateral forces are increased monolithically until the displacement of the top of the building reaches a predetermined displacement value (Inel and Ozmen, 2006; Antoniou and Pinho, 2004; Ișık and Kutanis, 2015; Jalayer et al., 2015). Typical pushover curve was given in Figure 1.

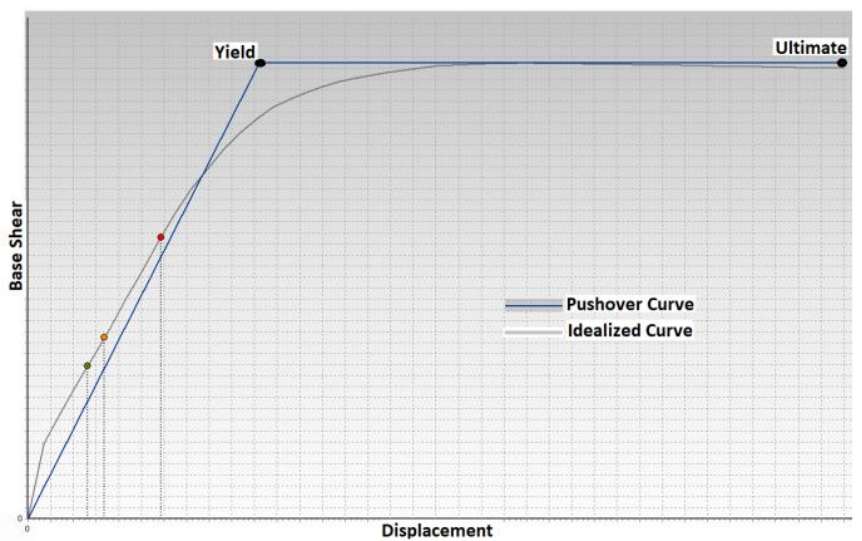

Figure 1. Typical pushover and idealized capacity curves

\section{Description of Sample Steel Structure and Modelling}

In this study, ZA local ground type that given in Eurocode-8 (Eurocode-8, 2005) was chosen as the local soil class for all structural models. The characteristics of this soil type (ZA) are given in Table 1.

Table 1. Local ground type ZA (Eurocode-8 2005)

\begin{tabular}{|c|c|c|c|c|}
\hline \multirow{4}{*}{$\begin{array}{c}\text { Ground } \\
\text { Type }\end{array}$} & \multirow{2}{*}{$\begin{array}{c}\text { Description of } \\
\text { stratigraphic profile }\end{array}$} & \multicolumn{3}{|c|}{ Parameters } \\
\cline { 3 - 5 } & $(\mathrm{VS})_{30}$ & NSPT & \\
{$[\mathrm{m} / \mathrm{s}]$} & $\begin{array}{c}\text { [blows } \\
/ 30 \mathrm{~cm}]\end{array}$ & $\begin{array}{c}(\mathrm{cu})_{30} \\
{[\mathrm{kPa}]}\end{array}$ \\
\hline \multirow{7}{*}{ ZA } & $\begin{array}{c}\text { Rock or other rock-like } \\
\text { geological like geological } \\
\text { formation, including at } \\
\text { most 5 m of weaker } \\
\text { material at the surface. }\end{array}$ & $>800$ & $-\cdots$ & $-\cdots$ \\
\hline
\end{tabular}

Material models have an important place in seismic analysis of the buildings (Işlk and Ozdemir, 2017). Calculations were made for steel model selected as Menegetto-Pinto steel model (stl_mp) (Menegotto, 1973) in this study. The stress-strain relationship of the material model is demonstrated in Figure 2. 


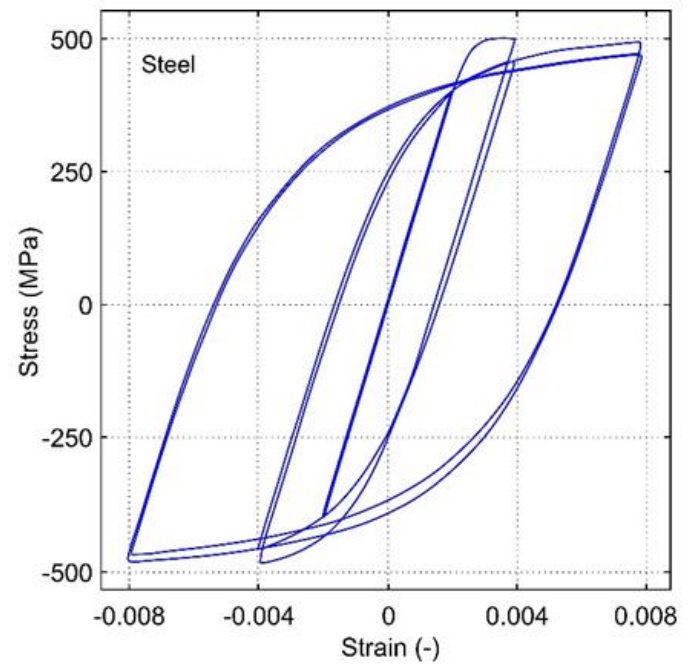

Figure 2. Material models for concrete and steel considered in the study

The cross-sectional representation and the dimensions of the selected profile are shown in Figure 3.

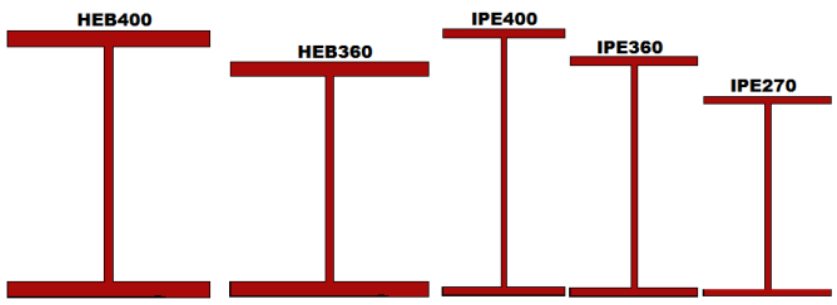

Figure 3. Cross sections of the steel profiles

The cross-section dimensions of profiles that used in this study are given in Table 2 .

Table 2. Cross section dimensions of the profiles

\begin{tabular}{|c|c|c|c|c|c|}
\hline Profile & $\begin{array}{c}\text { HEB } \\
360\end{array}$ & $\begin{array}{c}\text { HEB } \\
400\end{array}$ & $\begin{array}{c}\text { IPE } \\
270\end{array}$ & $\begin{array}{c}\text { IPE } \\
360\end{array}$ & $\begin{array}{c}\text { IPE } \\
400\end{array}$ \\
\hline $\begin{array}{c}\text { Bottom Flange } \\
\text { Width (m) }\end{array}$ & 0.3000 & 0.3000 & 0.1350 & 0.1700 & 0.1800 \\
\hline $\begin{array}{c}\text { Bottom Flange } \\
\text { Thickness (m) }\end{array}$ & 0.0225 & 0.0240 & 0.0102 & 0.0127 & 0.0135 \\
\hline $\begin{array}{c}\text { Top Flange } \\
\text { Width (m) }\end{array}$ & 0.3000 & 0.3000 & 0.1350 & 0.1700 & 0.1800 \\
\hline $\begin{array}{c}\text { Top Flange } \\
\text { Thickness (m) }\end{array}$ & 0.0225 & 0.0240 & 0.0102 & 0.0127 & 0.0135 \\
\hline Web height (m) & 0.3150 & 0.3520 & 0.2496 & 0.3346 & 0.3730 \\
\hline $\begin{array}{c}\text { Web Thickness } \\
(\mathrm{m})\end{array}$ & 0.0125 & 0.0135 & 0.0066 & 0.008 & 0.0086 \\
\hline
\end{tabular}

The floor plan of the steel structure considered in the study is shown in Figure 4.

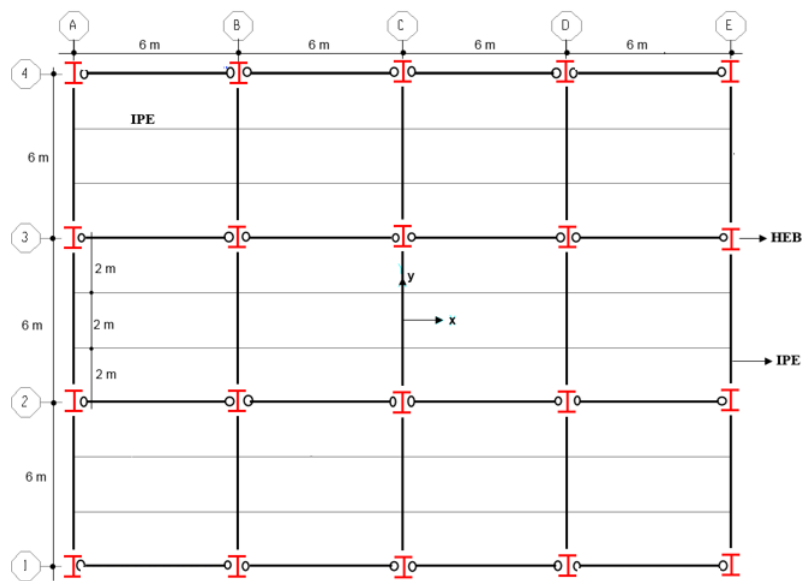

Figure 4. The plan of the sample steel structure

The 2D model of an exemplary axis of the steel structure considered in the study is given in Figure 5.

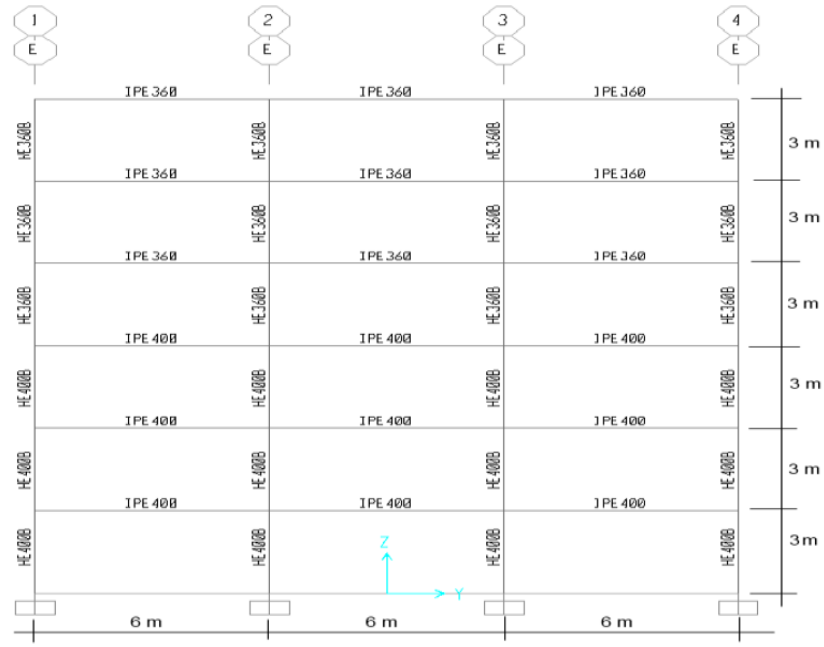

Figure 5. 2D model of the sample steel structure

The three-dimensional model obtained in the software for the structure and the loads that were applied are given in Figure 6. The loading condition is taken as a constant for all building models.
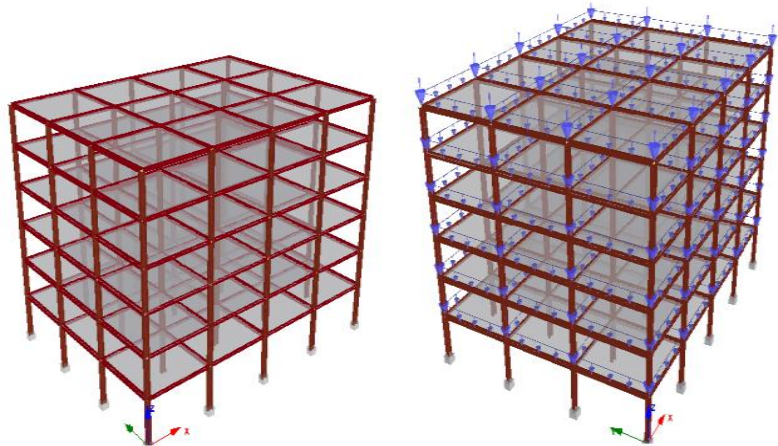

Figure 6. The 3D model and applied loads of the sample steel structure 
In performance-based Earthquake Engineering, determining target displacements is essential for damage estimation when definite performance limits of structural elements are reached. The limit states are given in Eurocode-8 (Part 3) (Eurocode, 2005; Pinto et al, 2011) were taken into account for damage assessment used universal in the structural analysis. The damage assessment of limit states are presented in Table 3, along with Eurocode-8. These values were computed for all building models.

Table 3. Limit states in Eurocode-8 (Part 3)

\begin{tabular}{|c|c|c|c|}
\hline Limit State & Description & $\begin{array}{c}\text { Return } \\
\text { Period } \\
\text { (year) }\end{array}$ & $\begin{array}{c}\text { Probability of } \\
\text { exceedance } \\
\text { (in 50 years) }\end{array}$ \\
\hline $\begin{array}{c}\text { Limit state } \\
\text { of damage } \\
\text { limitation } \\
\text { (DL) }\end{array}$ & $\begin{array}{c}\text { Only lightly damaged, } \\
\text { damage to non-structural } \\
\text { components economically } \\
\text { repairable }\end{array}$ & 225 & 0.20 \\
\hline $\begin{array}{c}\text { Limit state } \\
\text { of } \\
\text { significant } \\
\text { damage } \\
\text { (SD) }\end{array}$ & $\begin{array}{c}\text { Significantly damaged, } \\
\text { some residual strength } \\
\text { and stiffness, non- } \\
\text { structural components } \\
\text { damaged, uneconomic to } \\
\text { repair }\end{array}$ & 475 & 0.10 \\
\hline $\begin{array}{c}\text { Limit state } \\
\text { of near } \\
\text { collapse } \\
\text { (NC) }\end{array}$ & $\begin{array}{c}\text { Heavily damaged, very } \\
\text { low residual strength \& } \\
\text { stiffness, large permanent } \\
\text { drift but still standing }\end{array}$ & 2475 & 0.02 \\
\hline
\end{tabular}

Base shear forces for each structural model were calculated separately for both directions. The displacement at the moment of yield (dy), elastic stiffness (K_elas) and effective stiffness (K_eff) values were also calculated separately for all structural models.

\section{Main Negative Structural Parameters and Analysis Results}

Some properties of the structures closely affect the earthquake damages that occur. In this study, five main vulnerabilities that cause earthquake damages have been taken into consideration. The number of stories, soft story, short column, hill- slope effect and irregularity in the plan were chosen as variables in structural analysis in this study. The specified analyzes for each variable were made separately. The comparisons are made between reference model and building model with negativity.

\subsection{Number of Stories}

One of the factors causing structural damage is the total number of stories of the building. It is revealed that there is an almost linear relationship between the number of studies and building damage in buildings in previous observations and studies (Şengezer, 1999) Analyzes were carried out by selecting three different numbers of stories for this parameter. Story heights are taken as $3 \mathrm{~m}$ and equal in all stories in all structural models. Only the number of stories is taken as variable. Two-dimensional building models are shown in Figure 7.

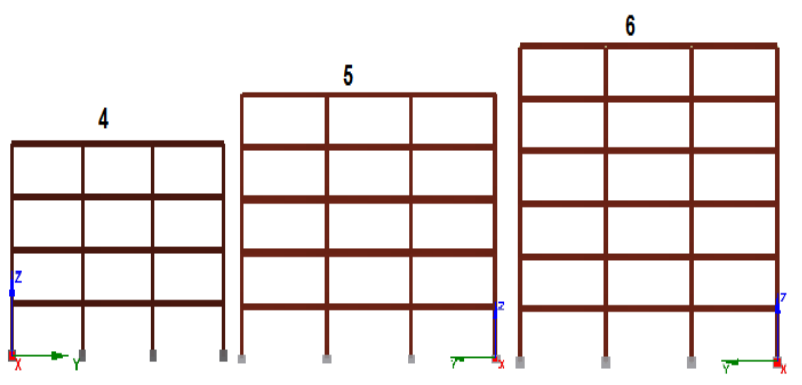

Figure 7. 2D models obtained for number of stories

Three-dimensional models obtained from the software of the selected structures, 4-story, 5-story and 6-story, are given in Figure 8.
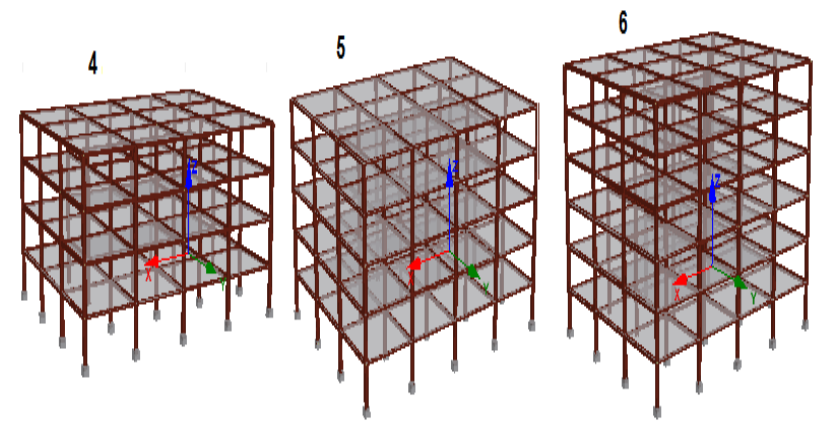

Figure 8. 3D models of the building models

Comparison of pushover analysis curves obtained for different story number in both direction is given in Figure 9.

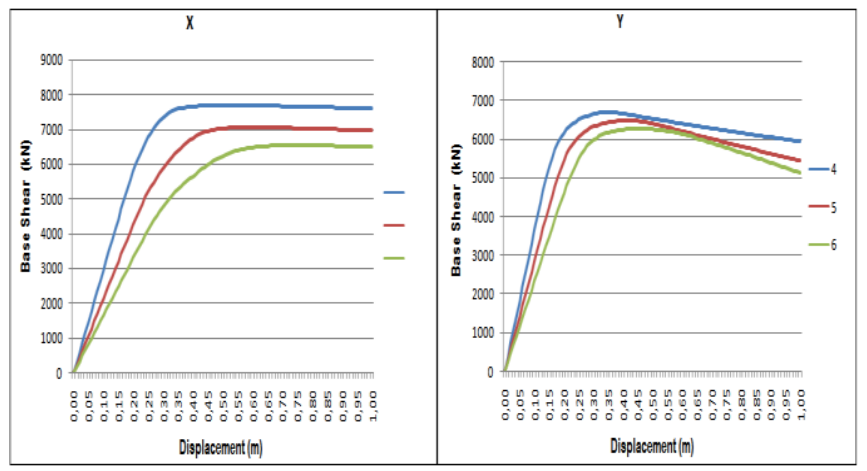

Figure 9. Comparison of pushover curves obtained for story change

The comparisons of eigenvalue and pushover analysis results are given in Table 4 . 
Table 4. Comparison of the values obtained for story change

\begin{tabular}{|c|c|c|c|c|c|c|c|c|c|}
\hline 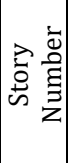 & 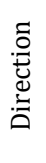 & 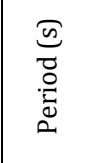 & 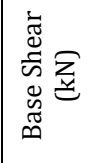 & 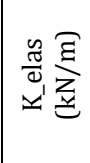 & 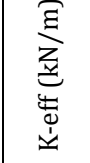 & $\begin{array}{l}\underset{\Xi}{g} \\
\vec{\theta}\end{array}$ & $\underset{\vec{\jmath}}{\stackrel{\Xi \Xi}{\Xi}}$ & 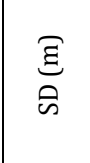 & 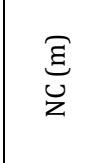 \\
\hline 6 & X & 0.406 & 6538 & 16485 & 14992 & 0.436 & 0.022 & 0.029 & 0.045 \\
\hline 5 & $X$ & 0.326 & 7052 & 21586 & 18224 & 0.355 & 0.014 & 0.017 & 0.031 \\
\hline 4 & $\mathrm{X}$ & 0.250 & 7683 & 33141 & 27913 & 0.275 & 0.00734 & 0.00942 & 0.01633 \\
\hline 6 & Y & 0.40579 & 6272.83 & 23248.5 & 22247.5 & 0.282 & 0.01591 & 0.02041 & 0.03539 \\
\hline 5 & $\mathrm{Y}$ & 0.32620 & 6489.65 & 28545.2 & 26906.8 & 0.241 & 0.01069 & 0.01371 & 0.02378 \\
\hline 4 & Y & 0.24991 & 6695.2 & 36451.8 & 33815.2 & 0.198 & 0.00650 & 0.00834 & 0.01446 \\
\hline
\end{tabular}

\subsection{Soft Story}

The stiffness and strength of any story in the building is significantly less than the other stories, creates the concept of soft story. Soft story can be occurring due to different characteristics between stories (such as the height of the stories), changing of the structural system, using different floors system or due to the change in the amount of partition walls that are not considered to belong to the structural system (Inel et al., 2011; Tezcan et al., 2007; Jara et al., 2020). Within the scope of this study, a soft story was created with the height of the ground story being higher than the other stories. The ground story height was chosen differently according to other story heights and analyzes were carried out according these structural models. The heights on the other stories remained constant in each model. Apart from this, all parameters that are essential for structural analysis are taken as the same in each model. In order to examine the ground story height change, three different building models have been created by taking the ground story height such as $3 \mathrm{~m}, 3.5 \mathrm{~m}$ and $4.0 \mathrm{~m}$. Twodimensional models of these structures are given in Figure 10.

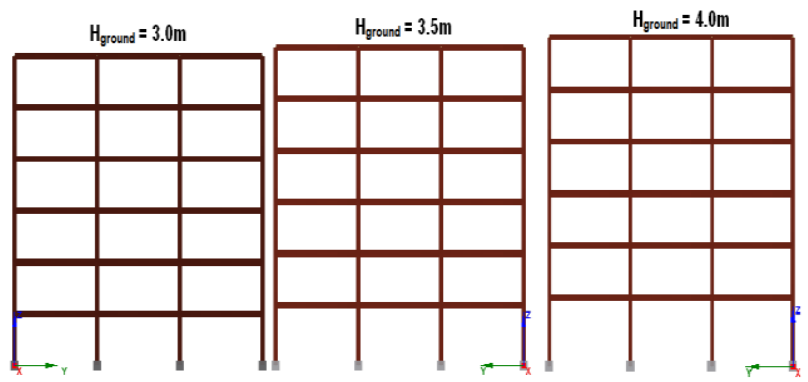

Figure 10. 2D models of the different ground story height

Comparison of the curves obtained as a result of pushover analysis in $\mathrm{X}$ and $\mathrm{Y}$ directions due to changing of ground story height are given in Figure 11.

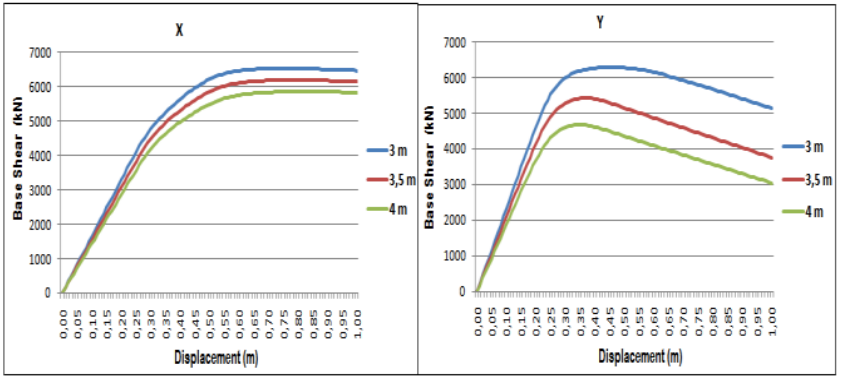

Figure 11. Comparison of pushover curves obtained for different ground story change

Comparison of analysis results values for changing ground story height is given in Table 5.

Table 5. Comparison of the results for ground story height change

\begin{tabular}{|c|c|c|c|c|c|c|c|c|c|}
\hline 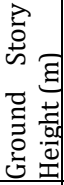 & 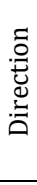 & 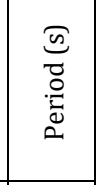 & 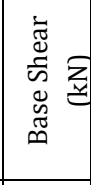 & 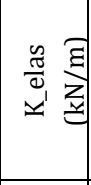 & 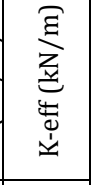 & $\underset{\vec{\partial}}{\stackrel{\Xi}{\Xi}}$ & $\underset{\overrightarrow{0}}{\stackrel{\Xi}{\Xi}}$ & 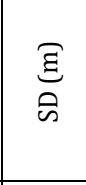 & $\underset{z}{\Xi}$ \\
\hline 3 & $X$ & 0.40579 & 6537.71 & 16485.2 & 14992.3 & 0.4361 & 0.02235 & 0.02867 & 0.04970 \\
\hline 3.5 & $\mathrm{X}$ & 0.42106 & 6191.32 & 15366.2 & 13977.6 & 0.443 & 0.02490 & 0.03190 & 0.05529 \\
\hline 4 & $\mathrm{X}$ & 0.43730 & 5870.31 & 14311.1 & 12984.5 & 0.452 & 0.02770 & 0.0356 & 0.06166 \\
\hline 3 & Y & 0.40579 & 6272.83 & 23248.5 & 22247.5 & 0.282 & 0.01591 & 0.02041 & 0.03539 \\
\hline 3.5 & Y & 0.42106 & 5421.24 & 21013.9 & 20222.7 & 0.268 & 0.01860 & 0.02380 & 0.04127 \\
\hline 4 & Y & 0.43730 & 4669.74 & 20479 & 18080.3 & 0.258 & 0.02190 & 0.02810 & 0.04876 \\
\hline
\end{tabular}

\subsection{Short Column}

Short columns may formed different ways. A column being shorter than the way it was originally designed in the building is defined with the concept of short column (Bal et al., 2008). Short columns may occur either because the original column length-to-depth ratio is small, or due to the presence of an obstacle along a certain height of the column (e.g. low brick masonry wall) in which case the effective length of the column is reduced and equals the column's unflanked length. (Moretti and Tassios, 2013; Chen et al., 2010; Çağatay et al., 2009). While creating the short column, the ground and 1st story height values in the building were chosen to be lower than the other stories. While all story heights are $3 \mathrm{~m}$, ground story height is $3.5 \mathrm{~m}$ and $2 \mathrm{nd}$ story height is $2.5 \mathrm{~m}$. The total height of the building has not been changed. Two-dimensional models of these structures are given in Figure 12. 


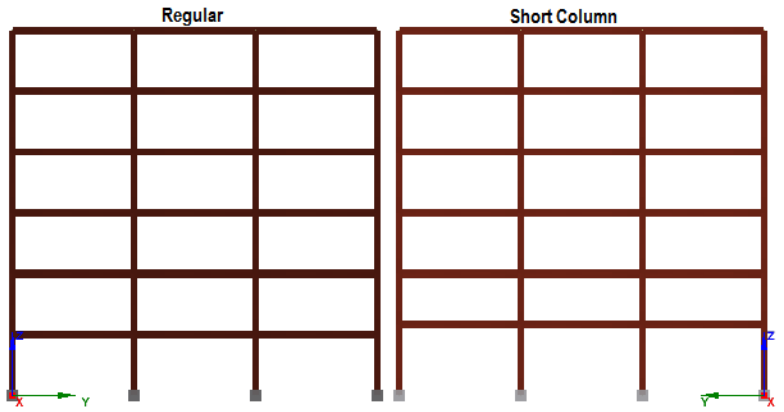

Figure 12. 2D models obtained for short column effect

Comparison of curves obtained as a result of static pushover analysis in $\mathrm{X}$ and $\mathrm{Y}$ directions due to short column change are given in Figure 13.

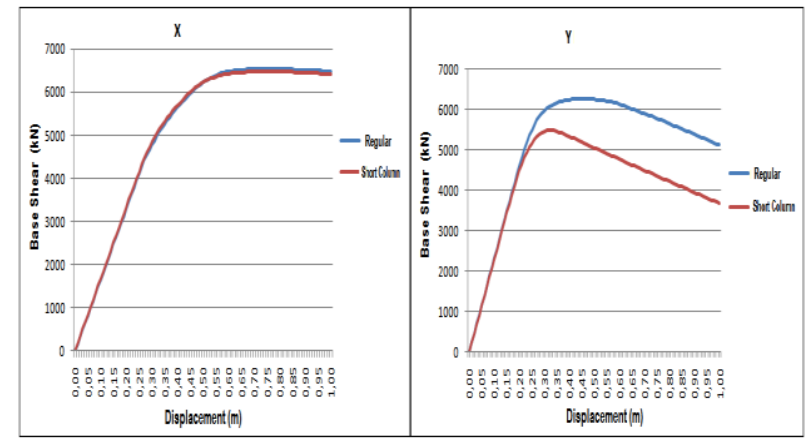

Figure 13. Pushover curves for short column

Comparison of analysis results values for short column is given in Table 6.

Table 6. Comparisons of results for short column

\begin{tabular}{|c|c|c|c|c|c|c|c|c|c|}
\hline $\begin{array}{l}\overline{0} \\
0 \\
\dot{0}\end{array}$ & 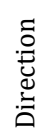 & 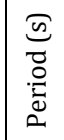 & 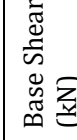 & 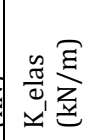 & 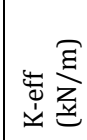 & $\underbrace{\overparen{E}}_{\vec{\theta}}$ & 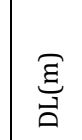 & $\underbrace{\Xi}_{\varrho}$ & $\underset{\bigcup}{\Xi}$ \\
\hline Reference & $\mathrm{X}$ & 0.405 & 6537.7 & 16485.2 & 14992.3 & 0.436 & 10.0223 & 0.0287 & 0.0497 \\
\hline $\begin{array}{c}\text { Short } \\
\text { Column }\end{array}$ & $\mathrm{X}$ & 0.402 & 6472.7 & 16668.3 & 15239.3 & 0.425 & 0.0221 & 0.0284 & 0.0493 \\
\hline Reference & Y & 0.405 & 6272.8 & 23248.5 & 22247.5 & 0.282 & 0.0159 & 0.0204 & 0.0354 \\
\hline $\begin{array}{c}\text { Short } \\
\text { Column }\end{array}$ & Y & 0.402 & 5489.5 & 22978.9 & 22224.6 & 0.247 & 0.0164 & 0.0210 & 0.0364 \\
\hline
\end{tabular}

\subsection{Hill-slope Effect}

The fact that the building is prominently on a hill or on a high slope will slightly increase the earthquake effects it will be exposed to or exposed to. For geological and topographic reasons, buildings have to be built under the influence of hillslope. As a result, level differences occur on the story where the building meets the ground. This situation creates height differences in the structural system elements and causes the formation of short and long columns (Mohammad et al., 2017; Tezcan et al., 2011). The structural models were created by reducing the height values of the columns on the ground story of the building while considering the hill - slope effect. Twodimensional building models obtained while considering the hill-slope effect are given in Figure 14.
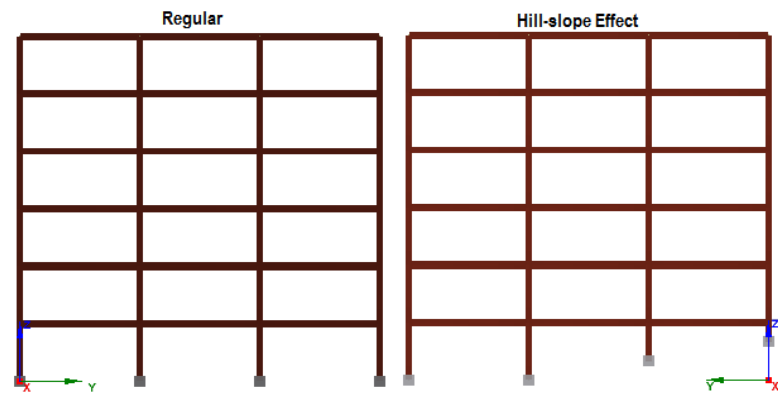

Figure 14. 2D models for hill-slope effect

Comparison of curves obtained as a result of pushover analysis in $\mathrm{X}$ and $\mathrm{Y}$ directions due to hill-slope effect are given in Figure 15.

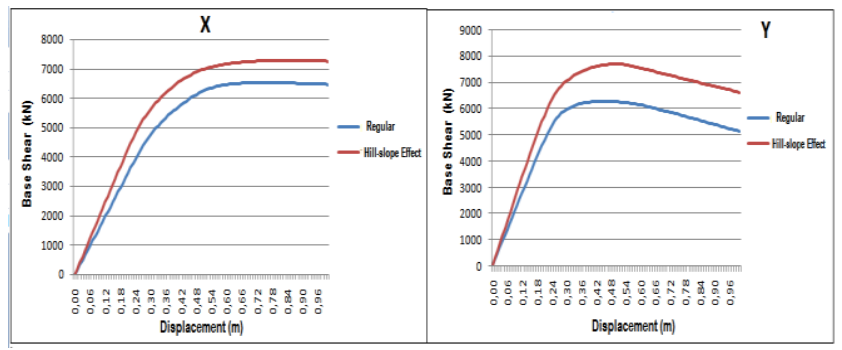

Figure 15. Comparisons of pushover curves for hill-slope effect

The comparison of analyses results for hill-slope effect is given in Table 7.

Table 7. Comparison of result values for the hill-slope effect

\begin{tabular}{|c|c|c|c|c|c|c|c|c|c|}
\hline $\begin{array}{l}\overline{0} \\
\overline{0} \\
\dot{\Sigma}\end{array}$ & 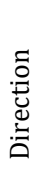 & $\begin{array}{l}\sqrt[0]{0} \\
0 \\
0 \\
0 \\
0 \\
0 \\
0\end{array}$ & 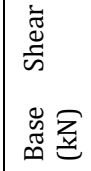 & 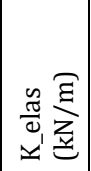 & 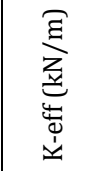 & 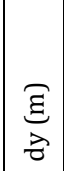 & 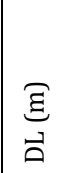 & $\underset{\text { है }}{\stackrel{\Xi}{g}}$ & 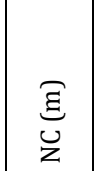 \\
\hline Reference & X & 0.405 & 6537.71 & 16485.2 & 14992.31 & 0.436 & 0.022 & 0.02867 & 0.04970 \\
\hline Hill-slope & $X$ & 0.384 & 7258.32 & 20476.6 & 17951.33 & 0.404 & 0.016 & 0.0214 & 0.0371 \\
\hline Reference & Y & 0.405 & 6272.83 & 23248.5 & 22247.51 & 0.282 & 0.016 & 0.02041 & 0.03539 \\
\hline Hill-slope & Y & 0.384 & 7697.63 & 28578.5 & 25952.23 & 0.297 & 0.012 & 0.0151 & 0.0262 \\
\hline
\end{tabular}

\subsection{Irregularity in Plan}

Structures can be built with irregularities in the plan instead of simple geometry like a rectangular plan due to various reasons. Seismic design codes suggest that the plan should not have as large indentations and protrusions as possible (TBEC-2018; Herrera and Soberon, 2008). The floor form plan of the reference building has been changed for the irregularity of the plan. Floor views of regular and irregular in plan were given in Figure 16. 

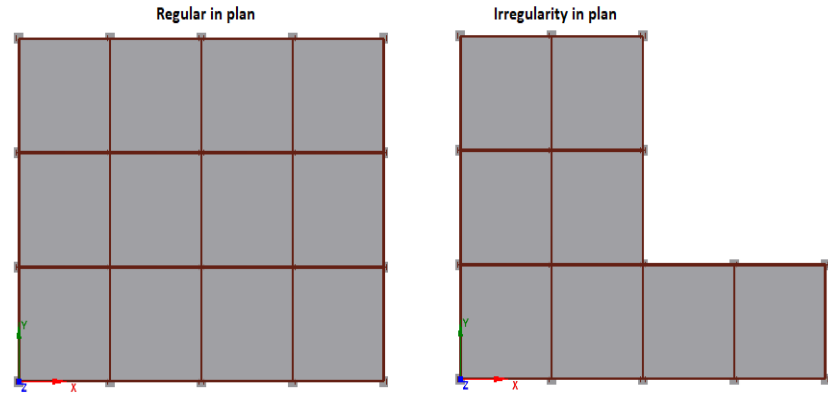

Figure 16. The plans for regular and irregular building model in plan

Three-dimensional models of both models were given in Figure 17.
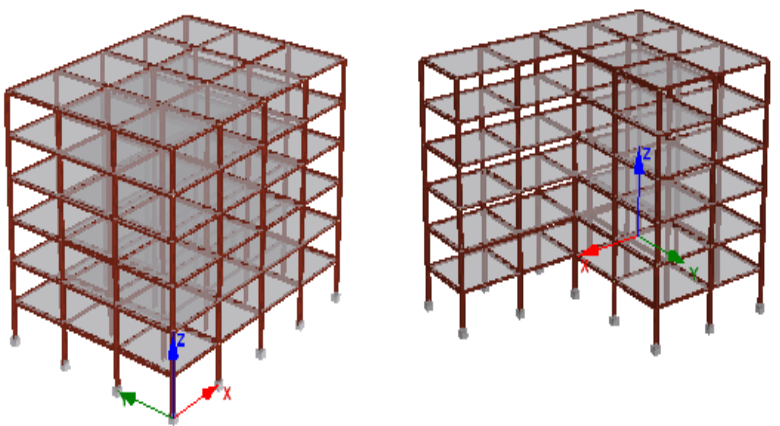

Figure 17. Three-dimensional models of structures with reference and irregular building models

Comparison of curves obtained as a result of pushover analysis in $\mathrm{X}$ and $\mathrm{Y}$ directions due to irregularity in plan are given in Figure 18.

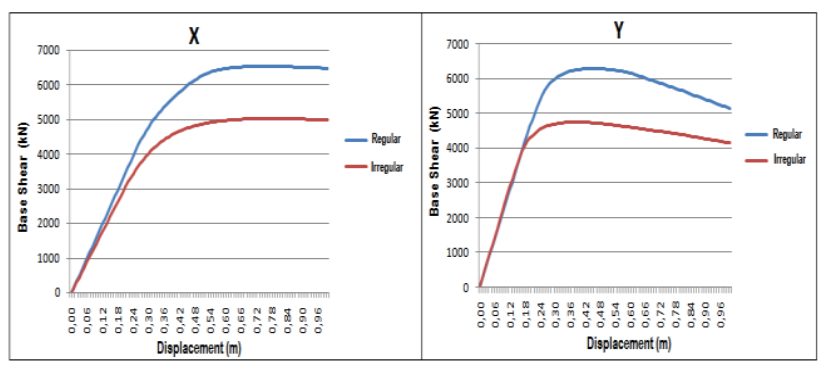

Figure 18. Comparisons of pushover curves for irregularity in plan

The comparisons of analyses result for irregularity in plan are given in Table 8.
Table 8. Comparison of result values for irregularity in plan

\begin{tabular}{|c|c|c|c|c|c|c|c|c|c|}
\hline $\begin{array}{l}\overline{0} \\
\overline{0} \\
\Sigma\end{array}$ & 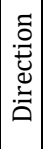 & $\begin{array}{c}0 \\
0 \\
0 \\
0 \\
0 \\
0 \\
0\end{array}$ & 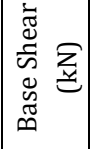 & $\begin{array}{l}\tilde{y} \\
\frac{\pi}{d} \\
x^{\prime} \\
z\end{array}$ & 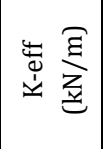 & 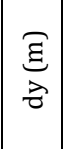 & 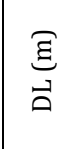 & 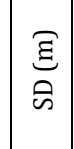 & 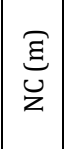 \\
\hline Reference & $\mathrm{X}$ & 0.406 & 6537.711 & 16485.21 & 14992.31 & 0.436 & 0.022 & 0.029 & 0.049 \\
\hline Irregularity & $\mathrm{X}$ & 0.405 & 5024.331 & 14569.97 & 13005.89 & 0.436 & 0.019 & 0.025 & 0.043 \\
\hline Reference & Y & 0.406 & 6272.832 & 23248.50 & 22247.51 & 0.282 & 0.016 & 0.021 & 0.035 \\
\hline Irregularity & & 0.405 & 733.24 & 39861 & 2437.8 & .282 & 0098 & .01 & 02 \\
\hline
\end{tabular}

\subsection{Local Soil Conditions}

It is a known fact that local ground conditions directly affect the seismic behavior of structures. In the analysis results obtained, the differentiation of local soil conditions did not change the results significantly. Therefore, in order to obtain more meaningful results, Turkish Earthquake Hazard Map application, which used for Turkish Building Earthquake Code (2018), was used to determine the effect of local soil conditions (AFAD, 2020). Turkish Earthquake Hazard Map Interactive Web Application has become available for the computation of earthquake parameters for any geographic location since the beginning of 2019. For this purpose, results were obtained according to different soil classes for any geographic location where the building will be built by using this application. Comparison of the values obtained as a result of this application is shown in Table 9.

Table 9. Change of parameters obtained for different soil conditions

\begin{tabular}{|c|c|c|c|c|c|}
\hline Parameter & ZA & ZB & ZC & ZD & ZE \\
\hline $\mathrm{F}_{\mathrm{S}}$ & 0.800 & 0.900 & 1.250 & 1.301 & 1.502 \\
\hline $\mathrm{F}_{1}$ & 0.800 & 0.800 & 1.500 & 2.246 & 3.507 \\
\hline $\mathrm{S}_{\mathrm{DS}}$ & 0.499 & 0.562 & 0.780 & 0.812 & 0.937 \\
\hline $\mathrm{S}_{\mathrm{D} 1}$ & 0.142 & 0.142 & 0.266 & 0.398 & 0.621 \\
\hline $\mathrm{T}_{\mathrm{A}}(\mathrm{s})$ & 0.057 & 0.050 & 0.068 & 0.098 & 0.132 \\
\hline $\mathrm{T}_{\mathrm{B}}(\mathrm{s})$ & 0.284 & 0.252 & 0.340 & 0.490 & 0.662 \\
\hline $\mathrm{T}_{\mathrm{AD}}(\mathrm{s})$ & 0.019 & 0.017 & 0.023 & 0.033 & 0.044 \\
\hline $\mathrm{T}_{\mathrm{BD}}(\mathrm{s})$ & 0.095 & 0.084 & 0.113 & 0.163 & 0.221 \\
\hline
\end{tabular}

Changes in the values obtained through this application related to the soil type given in TBEC-2018 are given in Table 10 . 
Table 10. Change of soil conditions parameters given (\%)

\begin{tabular}{|c|c|c|c|c|c|c|c|c|}
\hline $\begin{array}{c}\text { Soil } \\
\text { Type }\end{array}$ & $\mathrm{F}_{\mathrm{S}}$ & $\mathrm{F}_{1}$ & $\mathrm{~S}_{\mathrm{DS}}$ & $\mathrm{S}_{\mathrm{D} 1}$ & $\mathrm{~T}_{\mathrm{A}}$ & $\mathrm{T}_{\mathrm{B}}$ & $\mathrm{T}_{\mathrm{AD}}$ & $\mathrm{T}_{\mathrm{BD}}$ \\
\hline ZA & 0 & 0 & 0 & 0 & 0 & 0 & 0 & 0 \\
\hline ZB & 12.50 & 0.00 & 12.63 & 0.00 & 14.00 & 11.27 & 11.76 & 11.58 \\
\hline ZC & 56.25 & 87.50 & 56.31 & 87.32 & 19.30 & 19.72 & 21.05 & 18.95 \\
\hline ZD & 62.63 & 180.75 & 62.73 & 180.28 & 71.93 & 72.54 & 73.68 & 71.58 \\
\hline ZE & 87.75 & 338.38 & 87.78 & 337.32 & 131.58 & 133.10 & 131.58 & 132.63 \\
\hline Mean & 43.83 & 121.33 & 43.89 & 120.98 & 47.360 & 47.326 & 47.614 & 46.948 \\
\hline
\end{tabular}

\section{Conclusions and Discussions}

The lack of sufficient earthquake vulnerability of the buildings is one of the main causes of large-scale loss of life and property. Depending on the power of the seismic hazard, the possibility of damage to buildings varies depending on the weaknesses of the structures during design and construction. Several negative parameters in the structures directly affect the amount of damage that occurs. In this study, six different negative parameters such as number of story, soft story, short column, hill-slope effect, local soil conditions and irregularity in plan, which are the main causes of earthquake damages, have been taken into consideration. The effects of these parameters on the earthquake performance of buildings have been investigated based on pushover and eigenvalue analysis in terms of steel structures. The reduction coefficient for each parameter is proposed by evaluating all the obtained analysis results together.

There are many studies in the literature about the effects of single or multiple negativity parameters on earthquake vulnerabilities in RC structures due to more damage in the earthquakes. Therefore, studies on the subject of steel structures are limited and only one parameter should be considered in general. This study will have an important place in determining the earthquake vulnerability of steel structures with the same building characteristics but various negative parameters. In addition, the reduction coefficients obtained as a result of this study can be a source for their usability in rapid evaluation methods to be developed for steel structures.

In the scope of the study, for the total number of stories, which is the first parameter considered, three different numbers of stories were taken into account such as 4-, 5- and 6-story. As the number of stories increased, natural fundamental periods increased due to the decrease in stiffness values in both $\mathrm{X}$ and $\mathrm{Y}$ directions. The seismic capacity of steel structure was increased due to the decrease in the number of stories. The target displacements for damage estimation expected from the structure have increased according to the amount of the movement of the structures will increased due to higher periods. Therefore, as the number of stories increases, the level of vulnerability expected from the building will also increase. An average effect of $39 \%$ was obtained for number stories for this study by considering all analysis results.

The soft story was created by choosing the ground story height of the building higher than the other stories. The natural fundamental period of the structure increased, accordingly its rigidity and seismic capacities decreased for the ground floor height increased. With the consideration of all these values and the increase in the ground story height, the target displacements for damage estimation expected from the building have also increased. It showed an average of $51 \%$ change due to the soft story. The most unfavourable situation among all negativity parameters was obtained for soft story.

The column heights on the 1st story of the building were changed while creating the short column. In the case of a short column, although the period appears smaller and more rigid, the first damages were obtained under lower load conditions. The stiffness continuity expected from the building is interrupted by the change of column heights between stories. It showed an average of 5\% change due to the short column.

The column heights on the ground story have different heights according to the selected ground-slope for the hill-slope effect. In this case, the structure also has a short column situation. While the natural fundamental period value of the structure decreased under hill-slope effect, the rigidity and seismic capacity increased. The target displacements for damage estimation were decreased according to hill-slope effect. However, in the columns with the least height, the damage occurred at lower load conditions. The damage status of the structure showed that the earthquake vulnerability of the building was weakened due to the hill-slope effect. The exchange value obtained for this parameter is $10 \%$.

Only one case is taken into account for irregularity in the plan. In case of irregularity in the plan, the period of the structure increased, the stiffness value decreased and the seismic capacity decreased accordingly to these values. The target displacements for damage estimation were decreased for irregularity in the plan. Considering all the values obtained, the average change was calculated as $31 \%$ for irregularity in plan.

Local soil conditions directly affect the seismic behaviour of the structures. Close values were obtained for all soil conditions in the software. Therefore, the local ground coefficient values foreseen in TBEC-2018 were used. 47\% value was calculated as the change.

Within the scope of this study, the recommended reduction coefficients for six different parameters based on the analysis results are shown in Table 11.

Table 11. Recommended values for each parameter

\begin{tabular}{|c|c|}
\hline Parameter & Reduction Coefficient \\
\hline Soft story & 0.51 \\
\hline Short column & 0.05 \\
\hline Irregularity in plan & 0.31 \\
\hline Number of story & 0.39 \\
\hline Local soil conditions & 0.47 \\
\hline Hill-slope effect & 0.10 \\
\hline
\end{tabular}

In this study, each main parameter has been examined separately. It is useful to investigate how the earthquake performance of the structure will be in case of multiple parameters at the same time. In addition, only one different building model was taken into consideration in this study. Considering different types of building models in future studies will further support the results to be obtained. 
In cases where the number of stories is higher than the number of stories considered in the study, these values can be calculated for high-rise steel buildings, in future studies. Only one case for soft story, short column, hill-slope effect and irregularity in plan was considered in this study by using one software only. Different situations for main parameters and software can be considered to examine these main parameters in more detail in future studies.

\section{Conflicts of interest}

The authors declare that there are no conflicts of interest in the study.

\section{Acknowledgements}

This study produced from master thesis of second author.

\section{References}

Ademović, N., Šipoš, T. K., Hadzima-Nyarko, M. 2020. Rapid assessment of earthquake risk for Bosnia and Herzegovina. Bulletin of Earthquake Engineering, 18(5), 1835-1863.

AFAD, 2020. https://tdth.afad.gov.tr/ (Access date: 08.04.2020)

Aksoylu, C., Arslan, M.H. 2019. Çerçeve türü betonarme binaların periyod hesaplarının farklı ampirik bağıntılara göre irdelenmesi. Bitlis Eren Üniversitesi Fen Bilimleri Dergisi, 8(2), 569-581.

Alam, N., Alam, M. S., Tesfamariam, S. 2012. Buildings' seismic vulnerability assessment methods: a comparative study. Natural Hazards, 62(2), 405-424.

Antoniou, S., Pinho, R. 2003. Seismostruct - Seismic Analysis program by Seismosoft. Technical manual and user manual.

Antoniou, S., Pinho, R. 2004. Advantages and limitations of adaptive and non-adaptive force-based pushover procedures. Journal of Earthquake Engineering, 8(04), 497-522.

Antoniou, S., Pinho, R. 2004. Development and verification of a displacement-based adaptive pushover procedure. Journal of Earthquake Engineering, 8(05), 643-661.

Arslan, M. H., Ceylan, M., Koyuncu, T. 2015. Determining earthquake performances of existing reinforced concrete buildings by using ANN. International Journal of Civil and Environmental Engineering, 9(8), 1097-1101.

Aydinoğlu, M.N. 2003. An incremental response spectrum analysis procedure based on inelastic spectral displacements for multi-mode seismic performance evaluation. Bulletin of Earthquake Engineering, 1(1), 3-36.

Bal, I.E., Gulay, F.G., Tezcan, S.S. 2008. A new approach for the preliminary seismic assessment of RC buildings: P25 scoring method. Proceedings of 14th WCEE, 12-17.

Bracci, J.M., Kunnath, S.K., Reinhorn, A.M.1997. Seismic performance and retrofit evaluation of reinforced concrete structures. Journal of Structural Engineering, 123(1), 3-10.
Çağatay, İ.H., Beklen, C. 2009. Düzlem çerçevelerde kısa kolon etkisinin incelenmesi. Çukurova Üniversitesi MühendislikMimarlık Fakültesi Dergisi, 24(1), 91-97.

Chen, C.Y., Liu, K.C., Liu, Y.W., Huang, W.J. 2010. A case study of reinforced concrete short column under earthquake using experimental and theoretical investigations. Structural Engineering and Mechanics, 36(2), 197-206.

Chever, L. 2012. Use of seismic assessment methods for planning vulnerability reduction of existing building stock. In Proceedings of the 15th World Conference On Earthquake Engineering-WCEE, Lisbon, Portugal.

Chopra, A.K., Goel, R.K. 2002. A modal pushover analysis procedure for estimating seismic demands for buildings. Earthquake Engineering \& Structural Dynamics, 31(3), 561582.

Coburn, A., Spence, R. 2003. Earthquake Protection. John Wiley \& Sons.

Code, P. 2005. Eurocode 8: Design of structures for earthquake resistance-part 1: general rules, seismic actions and rules for buildings. Brussels: European Committee for Standardization.

Elnashai, A.S. 2001. Advanced inelastic static (pushover) analysis for earthquake applications. Structural Engineering and Mechanics, 12(1), 51-70.

Estêvão, J. M., Oliveira, C. S. 2015. A new analysis method for structural failure evaluation. Engineering Failure Analysis, 56, 573-584.

Eurocode, C.E.N. (2005). Eurocode-8: Design of structures for earthquake resistance-Part 3: Assessment and retrofitting of buildings, EN1998-3. European Committee for Standardization: Bruxelles, Belgium.

Gupta, B., Kunnath, S.K. 2000. Adaptive spectra - based pushover procedure for seismic evaluation of structures. Earthquake Spectra, 16(2), 367-392.

Hadzima-Nyarko, M., Kalman Sipos, T. 2017. Insights from existing earthquake loss assessment research in Croatia. Earthquakes and Structures, 13(4), 365-375.

Harirchian, E., Lahmer, T. 2020. Improved rapid visual earthquake hazard safety evaluation of existing buildings using a type-2 fuzzy logic model. Applied Sciences, 10(7), 2375.

Harirchian, E., Lahmer, T., Buddhiraju, S., Mohammad, K., Mosavi, A. 2020. Earthquake safety assessment of buildings through rapid visual screening. Buildings, 10(3), 51.

Harirchian, E., Lahmer, T., Kumari, V., Jadhav, K. 2020 Application of Support Vector Machine Modeling for the Rapid Seismic Hazard Safety Evaluation of Existing Buildings. Energies, 13(13), 3340.

Herrera, R. G., Soberon, C.G. 2008. Influence of plan irregularity of buildings. In The 14th World Conference on Earthquake Engineering.

Hsiao, F. P., Oktavianus, Y., Ou, Y. C. 2015. A pushover seismic analysis method for asymmetric and tall buildings. Journal of the Chinese Institute of Engineers, 38(8), 991-1001. 
Inel, M., Meral, E. 2016. Seismic performance of RC buildings subjected to past earthquakes in Turkey. Eartquakes and Structures, 11(3), 483-503.

Inel, M., Ozmen, H.B. 2006. Effects of plastic hinge properties in nonlinear analysis of reinforced concrete buildings. Engineering Structures, 28(11), 1494-1502.

İnel, M., Özmen, H.B., Hıra, M.A. 2011. Yumuşak kat düzensizliğinin betonarme yapıların sismik davranışına etkilerinin değerlendirilmesi. TMMOB İnșaat Mühendisleri Odası İstanbul Şubesi, 7. Deprem Konferansı, Türkiye.

Işık, E. 2016. Consistency of the rapid assessment method for reinforced concrete buildings. Earthquakes and Structures, 11(5), 873-885.

Işık, E., Işık, M. F., Bülbül, M. A. 2017. Web based evaluation of earthquake damages for reinforced concrete buildings. Eartquakes and Structures, 13(4), 423-432.

Işık, E., Kutanis M., 2015. Performance based assessment for existing residential buildings in Lake Van basin and seismicity of the region. Earthquakes and Structures, 9(4), 893-910.

Işık, E., Özdemir, M. 2017. Performance based assessment of steel frame structures by different material models. International Journal of Steel Structures, 17(3), 1021-1031.

Işık, M. F., Işık, E., Bülbül, M.A. 2018. Application of iOS/Android based assessment and monitoring system for building inventory under seismic impact. Gradevinar, 70(12), 1043-1056.

Jain, S. K., Mitra, K., Kumar, M., Shah, M. 2010. A proposed rapid visual screening procedure for seismic evaluation of RC-frame buildings in India. Earthquake Spectra, 26(3), 709-729.

Jalayer, F., De Risi, R., Manfredi, G. 2015. Bayesian Cloud Analysis: efficient structural fragility assessment using linear regression. Bulletin of Earthquake Engineering, 13(4), 1183 1203

Jara, J. M., Hernández, E. J., Olmos, B. A., Martínez, G. 2020. Building damages during the September 19, 2017 earthquake in Mexico City and seismic retrofitting of existing first softstory buildings. Engineering Structures, 209, 109977.

Krawinkler, H.,Seneviratna, G.D.P.K. 1998. Pros and cons of a pushover analysis of seismic performance evaluation. Engineering Structures, 20(4-6), 452-464.

Kutanis, M., Boru, E. O., Işık, E. 2017. Alternative instrumentation schemes for the structural identification of the reinforced concrete field test structure by ambient vibration measurements. KSCE Journal of Civil Engineering, 21(5), 1793-1801.

Luo, Y. F., Liu, Y. P., Hu, Z. Y., Xiong, Z. 2017. A new method for dynamic analysis of spatial lattice structures based on mode selection and mode construction techniques. International Journal of Steel Structures, 17(3), 1157-1170.

Menegotto, M. 1973. Method of analysis for cyclically loaded RC plane frames including changes in geometry and non-elastic behavior of elements under combined normal force and bending. In Proc. of IABSE symposium on resistance and ultimate deformability of structures acted on by well-defined repeated loads (pp. 15-22).

Mohammad, Z., Baqi, A., Arif, M. 2017. Seismic response of RC framed buildings resting on hill slopes. Procedia Engineering, 173, 1792-1799.

Moretti, M.L., Tassios, T.P. 2013. Design in shear of reinforced concrete short columns. Earthquakes and Structures, 4(3), 265-283.

Nikoo, M., Hadzima-Nyarko, M., Khademi, F., Mohasseb, S. 2017. Estimation of fundamental period of reinforced concrete shear wall buildings using self-organization feature map. Structural Engineering and Mechanics, 63(2), 237-249.

Ozcebe, G., Yucemen, M. S., Aydogan, V., \& Yakut, A. H. M. E. T. (2003). Preliminary seismic vulnerability assessment of existing reinforced concrete buildings in Turkey. In Seismic Assessment and Rehabilitation of Existing Buildings (pp. 2942). Springer, Dordrecht.

Ozmen, H.B., Inel, M., Meral, E. 2014. Evaluation of the main parameters affecting seismic performance of the RC buildings. Sadhana, 39(2), 437-450.

Papanikolaou, V.K., Elnashai, A.S. 2005. Evaluation of conventional and adaptive pushover analysis I: Methodology. Journal of Earthquake Engineering, 9(06), 923-941.

Pavić, G., Hadzima-Nyarko, M., Bulajić, B. 2020. A contribution to a uhs-based seismic risk assessment in Croatia-a case study for the city of Osijek. Sustainability, 12(5), 1796.

Pinto, P.E. Franchin, P. Eurocode 8-Part 3: Assessment and retrofitting of buildings. Eurocode 8 Background and Applications, Dissemination of Information for Training. 2011, Lisbon, Portugal.

Seismosoft. SeismoStruct 2018- A Computer program for static and dynamic nonlinear analysis of framed structures,2018, available from http://www.seismosoft. com.

Şengezer, S.B. 1999. Mart 1992 Erzincan Depremi Hasar Analizi ve Türkiye'de Deprem Sorunu. YT Ü. Basın Yayın Merkezi.

Šipoš, T. K., Hadzima-Nyarko, M. 2017. Rapid seismic risk assessment. International Journal of Disaster Risk Reduction, $24,348-360$

Sucuoglu, H., Yazgan, U. 2003. Simple survey procedures for seismic risk assessment in urban building stocks. In Seismic assessment and rehabilitation of existing buildings (pp. 97118). Springer, Dordrecht.

Sucuoğlu, H., Yazgan, U., Yakut, A. 2007. A screening procedure for seismic risk assessment in urban building stocks. Earthquake Spectra, 23(2), 441-458.

TBEC-2018, Turkish Building Earthquake Code. Ankara, Turkey.

Tesfamariam, S., Liu, Z. 2010. Earthquake induced damage classification for reinforced concrete buildings. Structural Safety, 32(2), 154-164. 
Tezcan, S., Yazici, A., Özdemir, Z., Erkal, A. 2007. Zayıf kat yumuşak kat düzensizliği. Altıncı Ulusal Deprem Mühendisliği Konferansi, 339-350.

Tezcan, S.S., Bal, I.E., Gulay, F.G. 2011. P25 scoring method for the collapse vulnerability assessment of R/C buildings. Journal of the Chinese Institute of Engineers, 34(6), 769-781.

Yakut, A. 2004. Preliminary seismic performance assessment procedure for existing RC buildings. Engineering Structures, 26(10), 1447-1461.
Yakut, A., Erberik, M. A., Ilki, A., Sucuoğlu, H., Akkar, S. 2014. Rapid Seismic Assessment Procedures for the Turkish Building Stock. In Seismic Evaluation and Rehabilitation of Structures (pp. 15-35). Springer, Cham.

Zuo, Y., Zha, X. 2018. FEM and experimental study on mechanical property of integrated container building. International Journal of Steel Structures, 18(2), 699-718. 